\title{
EFFECT OF ENOS GENE POLYMORPHISM ON THE COURSE OF EARLY ONSET BACTERIAL INFECTIONS IN PREMATURE INFANTS
}

DOI: 10.36740/WLek202006130

\author{
Yuliia I. Cherniavska', Valeriy I. Pokhylko', Tetiana K. Znamenska², Olga V. Vorobiova ${ }^{2}$, Nataliia I. Hasiuk' \\ 'UKRAINIAN MEDICAL STOMATOLOGICAL ACADEMY, POLTAVA, UKRAINE \\ 2SI"INSTITUTE OF PEDIATRICS, OBSTETRICS AND GYNECOLOGY NAMED AFTER ACADEMICIAN O.LUKYANOVA NAMS OF UKRAINE”, KYIV, UKRAINE
}

\begin{abstract}
The aim of the study was to analyze the associations between $4 \mathrm{a} / 4 \mathrm{~b}$ polymorphism of the eNOS gene and impaired systemic hemodynamics in premature infants with early neonatal sepsis.

Materials and methods: We conducted a prospective cohort study, which included 120 premature babies with early neonatal sepsis, in 57 children the course of the disease was accompanied by arterial hypotension (AH) and in 61 children - not. In children of both groups, genotyping was performed to determine 4a/4b polymorphism of the eNOS gene. Results: It was shown that the heart rate, blood pressure, hourly diuresis, the level of total nitrates and nitrites in the urine, as well as a number of echocardioscopic and dopplerometric indicators in children with different eNOS gene genotypes are not different.

Conclusions: There is no effect of $4 \mathrm{a} / 4 \mathrm{~b}$ polymorphism of the eNOS gene on the occurrence of hemodynamic disturbances in premature infants with sepsis.
\end{abstract}

KEY WORDS: premature infants, early sepsis, eNOS gene, 4a / 4b polymorphism, hemodynamics, total nitrates and nitrites

Wiad Lek. 2020;73(6):1237-1240

\section{INTRODUCTION}

In Ukraine, infections of the perinatal period, congenital pneumonia, sepsis occupy 3-4 place in the structure of morbidity and mortality of newborns. Among the causes of mortality, the proportion of infections is $23-25 \%$, and in intensive care units - up to $40-60 \%$ [1]. A common cause of death and severe complications in newborns is septic shock, which occurs in deeply premature babies due to several causes. Various pathogenic factors lead to the activation of the sympathoadrenal system, the release of catecholamines and the appearance of generalized vasospasm. Prolonged centralization of blood circulation due to the action of stress factors or the rapid depletion of the compensatory capabilities of a morpho-functionally immature organism leads to progressive tissue hypoxia and the formation of "capillary leak syndrome". It is now known that endothelium regulates vascular tone through the release of vasodilating and vasoconstrictor factors and modulates the contractile activity of smooth muscle cells. Endothelial dilatation factors include nitric oxide (NO). Under physiological conditions, NO is constantly involved in adapting the vascular system to increased metabolic needs and physical activity. Nitric oxide prevents platelet adhesion and aggregation, monocyte adhesion, protects the vascular wall and prevents vascular remodeling in various pathological conditions. Also, this molecule regulates the balance between mitosis and apoptosis of cells [2]. Therefore, we hypothesized that eNOS gene polymorphism may be associated with impaired hemodynamics in premature infants with early neonatal sepsis.

Nitric oxide in the human body can be formed from L-arginine with the participation of the enzyme of the gene for endothelial NO synthase (eNOS) [3] and the nitrite pathway in ischemic and postischemic tissues [4]. Several polymorphic regions were found in the exons and introns of the eNOS gene, among which the most studied is the mini-satellite repeat in intron 4 (eNOS $4 \mathrm{a} / 4 \mathrm{~b}$ polymorphism). The $4 \mathrm{a} / 4 \mathrm{~b}$ mini-satellite in the 4 th intron of the eNOS gene has 2 alleles, which consist of 4 or 5 tandem repeats of 27 nucleotide pairs in size. The normal variant has 5 repeats (denoted by $4 \mathrm{~b}$ ), and the mutant variant has 4 repeats (4a). The effect of option $4 \mathrm{a}$ is associated with impaired eNOS gene expression, which leads to a decrease in nitric oxide production. The relationship between the level of NO production in the body and the severity of oxidative stress during vascular pathology is clearly traced: inhibition of synthesis and a sharp decrease in nitric oxide in the bloodstream are associated with the accumulation of free radical molecules. Homozygous carriers of the $4 \mathrm{~N}$ allele of the eNOS gene revealed a significantly lower content of extracellular superoxide dismutase [5]. Anions $\mathrm{NO}_{2}$ and $\mathrm{NO}_{3}$ are the end products of the metabolism of nitric oxide in the human body, in which each NO molecule is converted at the end of the metabolic pathway to either $\mathrm{NO}_{2}$ or $\mathrm{NO}_{3}[3,4]$. The synthesized nitric oxide is excreted as $\mathrm{NO}_{2}$ and $\mathrm{NO}_{3}$ mainly (95\%) in urine [6]. 


\section{THE AIM}

The aim of the study was to analyze the associations between $4 \mathrm{a} / 4 \mathrm{~b}$ polymorphism of the eNOS gene and impaired systemic hemodynamics in premature infants with early neonatal sepsis.

\section{MATERIALS AND METHODS}

We conducted a prospective cohort study, which included 120 premature babies with early neonatal sepsis, in 57 children the course of the disease was accompanied by arterial hypotension $(\mathrm{AH})$ and in 61 children - not. All children were treated in the neonatal intensive care units of children's hospitals in the Poltava city. In children of both groups, genotyping was performed to determine $4 \mathrm{a} / 4 \mathrm{~b}$ polymorphism of the eNOS gene. The subject of the study is the clinical indicators that characterize systemic hemodynamics, the level of total nitrates and nitrites in the urine, as well as a number of echocardioscopic and dopplerometric indicators in premature infants, depending on the presence or absence of $4 \mathrm{a}$ allele of eNOS in a child.

Criteria for inclusion in the study: the presence of clinical symptoms (tachycardia, tachypnea, desaturation, apnea, impaired perfusion, seizures, shock) and laboratory criteria (the number of leukocytes is more than $20 \times 10^{9}$ or less than $5 \times 10^{9}$ and an increased level of C-reactive protein) of sepsis. Confirmation of sepsis, but not a mandatory criterion for inclusion in the main group, was the determination of a positive blood culture. Arterial hypotension was determined by the presence of episodes of lowered blood pressure in the child - the mean blood pressure in millimeters of mercury is less than the gestational age of the child in weeks, according to the record in the intensive care card. The material for this study was the peripheral blood of the newborn. Blood sampling was performed in a volume of $0.25 \mathrm{ml}$. After the procedure of isolating DNA samples from the obtained material, a molecular genetic study was carried out using a polymerase chain reaction and determining the polymorphism of restriction fragments length. Restriction of alleles of the eNOS gene was carried out using the BanII enzyme (Fermentas, USA). Amplified fragments were distributed using horizontal electrophoresis in a $1.5 \%$ agarose gel stained with ethidium bromide.

Constant variables are presented as mean values (M) and standard errors (m), categorical variables as absolute numbers and percentages. Student's test was used to compare independent samples and a chi-square test to compare proportions. All statistical analyzes were performed using the STATA version 11, licensed computer program package for Windows (StataCorp, Texas, USA).

\section{RESULTS AND DISCUSSION}

The distribution of newborns stratified according to variants $4 \mathrm{a} / 4 \mathrm{~b}$ of the eNOS gene polymorphism was identical among the studied groups. In premature infants with arterial hypotension, any child was identified with genotype $4 \mathrm{a} / 4 \mathrm{a}$, genotype $4 \mathrm{a} / 4 \mathrm{~b}$ was revealed in $56.25 \%$ of children and genotype $4 \mathrm{~b} / 4 \mathrm{~b}$ - in $43.75 \%$. In the group of children without arterial hypotension, genotype $4 \mathrm{a} / 4 \mathrm{a}$ was detected in $3.88 \%$ of children (OR $0, \mathrm{p}=0.577$ ), genotype $4 \mathrm{a} / 4 \mathrm{~b}-$ in $63.73 \%$ of children (OR $1.69, \mathrm{p}=0.235)$ and genotype $4 \mathrm{~b} / 4 \mathrm{~b}$ - in $32.35 \%$ of children (OR $0.65, \mathrm{p}=0.422$ ). Given the small number of children with $4 \mathrm{a} / 4 \mathrm{a}$ polymorphism, we combined children with the $4 \mathrm{a}$ allele in one group.

The analysis of medical and demographic indicators in premature infants with early sepsis, stratified according to the eNOS gene genotypes, did not reveal significant differences in such indicators as weight, gestational age at birth, and gender. The Apgar score at 1 and 5 minutes of life, as well as the frequency of usage of primary resuscitation measures in children with genotypes $4 a / 4 a \&$ $4 \mathrm{a} / 4 \mathrm{~b}$ and $4 \mathrm{~b} / 4 \mathrm{~b}$, was almost identical. Thus, the medical demographic indicators and the condition of children at birth with different genotypes of the eNOS gene did not differ significantly, which enabled us to minimize the influence of side factors and correctly evaluate the effect of gene polymorphism on the development of systemic hemodynamics disorders in premature babies.

The study did not reveal significant differences in heart rate and blood pressure on the 1st and 6th day in children with different genotypes of the eNOS gene (Table I). It is known that urine output is an indicator that, in addition to renal function, also characterizes systemic hemodynamics, in our study, the hourly diuresis in children with genotypes $4 \mathrm{a} / 4 \mathrm{a} \& 4 \mathrm{a} / 4 \mathrm{~b}$ and $4 \mathrm{~b} / 4 \mathrm{~b}$ was almost the same.

Thus, children with different $4 \mathrm{a} / 4 \mathrm{~b}$ variants of the eNOS gene did not have significant differences in hemodynamic parameters. A proof of this is the frequency of use of their hemodynamic support. Thus, dopamine (40\% and 37.8\%, respectively, $\mathrm{p}=0.482$ ), dopamine in combination with dobutamine $(18.7 \%$ and $20 \%$, respectively, $\mathrm{p}=0.519)$ or adrenaline $(4.1 \%$ and 0 , respectively, $\mathrm{p}=0.176)$ were administered for almost the same number of children with genotype variants $4 \mathrm{a} / 4 \mathrm{a} \& 4 \mathrm{a} / 4 \mathrm{~b}$ and $4 \mathrm{~b} / 4 \mathrm{~b}$. The mean age at which dopamine was prescribed was virtually the same (28.8 \pm 2.16 hours in children with the $4 \mathrm{a} / 4 \mathrm{a} \& 4 \mathrm{a} / 4 \mathrm{~b}$ genotype and $26.4 \pm 2.64$ hours in children with the 4 bb genotype $(\mathrm{p}=$ 0.495 ). The maximum dose of dopamine was slightly higher in children with genotypes $4 \mathrm{a} / 4 \mathrm{a} \& 4 \mathrm{a} / 4 \mathrm{~b}$, compared with children who had genotype $4 \mathrm{~b} / 4 \mathrm{~b}-7.4 \pm 1.0 \mu \mathrm{g} / \mathrm{kg} / \mathrm{min}$ and $6.1 \pm 0.75 \mu \mathrm{g} / \mathrm{kg} / \mathrm{min}$, respectively $(\mathrm{p}=0.276)$.

The results of a number of studies indicate that the polymorphism of the eNOS gene affects the level of synthesis of NO [4-5], a local vascular relaxation factor, therefore, we studied the levels of total nitrates and nitrites in the urine of premature babies with sepsis, depending on the type of genotype. There were no significant differences in the average values of this indicator in the examined children. So, on the 1-2 day of life, in children with genotype $4 \mathrm{a} / 4 \mathrm{a}$ $\& 4 \mathrm{a} / 4 \mathrm{~b}$, the level of $\mathrm{NO}_{2}+\mathrm{NO}_{3}$ was $89.6 \pm 8.4 \mathrm{mmol} / \mathrm{l}$, in children with genotype $4 \mathrm{~b} / 4 \mathrm{~b}$ it was $68.5 \pm 12.7 \mathrm{mmol} / \mathrm{l}$, $\mathrm{p}=0.178$; on the 6 th day, respectively, $73.1 \pm 7.2 \mathrm{mmol} / \mathrm{l}$ and $59.9 \pm 11.6 \mathrm{mmol} / \mathrm{l}, \mathrm{p}=0.345$.

To understand the pathogenesis of hemodynamic disturbances in preterm infants with sepsis, we compared echo- 
Table I. Indicators of systemic hemodynamics in premature infants with early sepsis, stratified in accordance with the variants of the eNOS gene genotype, $M \pm m$

\begin{tabular}{|c|c|c|c|}
\hline Indicators & $\begin{array}{c}\text { Genotype } \\
4 a / 4 a \& 4 a / 4 b \\
n=73\end{array}$ & $\begin{array}{c}\text { Genotype } \\
\begin{array}{c}4 b / 4 b \\
n=47\end{array}\end{array}$ & $\mathbf{p}$ \\
\hline $\begin{array}{l}1^{\text {st }} \text { day after birth } \\
\text { HR (beats per min) }\end{array}$ & $152,7 \pm 1,55$ & $154,3 \pm 2,32$ & 0,569 \\
\hline BP systolic $(\mathrm{mmHg})$ & $53,8 \pm 1,03$ & $54,8 \pm 1,34$ & 0,557 \\
\hline BP dyastolic $(\mathrm{mmHg})$ & $26,0 \pm 0,89$ & $27,1 \pm 1,11$ & 0,434 \\
\hline BP mean $(\mathrm{mmHg})$ & $32,5 \pm 0,82$ & $33,7 \pm 1,21$ & 0,412 \\
\hline Urine output (ml/kg/min) & $2,3 \pm 0,20$ & $2,0 \pm 0,15$ & 0,142 \\
\hline $\begin{array}{l}6^{\text {th }} \text { day after birth } \\
\text { HR (beats per min) }\end{array}$ & $154,6 \pm 1,43$ & $153,3 \pm 2,15$ & 0,612 \\
\hline BP systolic (mmHg) & $61,1 \pm 0,87$ & $63,2 \pm 0,77$ & 0,067 \\
\hline BP dyastolic $(\mathrm{mmHg})$ & $30,8 \pm 0,80$ & $33,1 \pm 0,98$ & 0,066 \\
\hline BP mean $(\mathrm{mmHg})$ & $37,3 \pm 0,75$ & $39,3 \pm 0,93$ & 0,088 \\
\hline $\begin{array}{l}\text { Urine output } \\
\text { (ml/kg/min) }\end{array}$ & $4,0 \pm 0,17$ & $4,0 \pm 0,21$ & 0,937 \\
\hline
\end{tabular}

Table II. Echocardioscopic and dopplerometric indicators that characterize systemic and organ hemodynamics in prematurely born children stratified in accordance with the eNOS gene genotypes, $\mathrm{M} \pm \mathrm{m}$

\begin{tabular}{|c|c|c|c|}
\hline Indicators & $\begin{array}{c}\text { Genotype } \\
4 a a \& 4 a b \\
n=73\end{array}$ & $\begin{array}{c}\text { Genotype } \\
\begin{array}{c}4 b b \\
n=47\end{array}\end{array}$ & $\mathbf{p}$ \\
\hline $\begin{array}{l}\text { Minute heart volume } \\
(\mathrm{ml} / \mathrm{min})\end{array}$ & $569,8 \pm 39,9$ & $627,4 \pm 58,0$ & 0,418 \\
\hline $\begin{array}{l}\text { Impact Index } \\
\left(1 / \mathrm{min}^{*} \mathrm{~m}^{2}\right)\end{array}$ & $3,7 \pm 0,27$ & $4,6 \pm 0,44$ & 0,101 \\
\hline $\begin{array}{l}\text { The shock index of } \\
\text { the work of the left } \\
\text { ventricle }\left(g^{*} \mathrm{~min} / \mathrm{m}^{2}\right)\end{array}$ & $1,3 \pm 0,12$ & $1,7 \pm 0,23$ & 0,112 \\
\hline $\begin{array}{l}\text { Cardiac Index } \\
\left(1 / \mathrm{min}^{*} \mathrm{~m}^{2}\right)\end{array}$ & $3,8 \pm 0,24$ & $4,0 \pm 0,29$ & 0,556 \\
\hline Impact volume (ml) & $3,7 \pm 0,26$ & $4,3 \pm 0,37$ & 0,193 \\
\hline Ejection fraction (\%) & $70,8 \pm 1,14$ & $68,7 \pm 2,16$ & 0,387 \\
\hline $\begin{array}{c}\text { Myocardial } \\
\text { contractility (\%) }\end{array}$ & $37,7 \pm 0,95$ & $36,2 \pm 1,64$ & 0,444 \\
\hline $\begin{array}{c}\text { Total peripheral } \\
\text { vascular resistance } \\
\left(\text { dyn* }^{*} / \mathrm{cm}^{5}\right)\end{array}$ & $5329,7 \pm 399$ & $4650,1 \pm 570$ & 0,334 \\
\hline $\begin{array}{l}\text { Middle cerebral artery } \\
\text { resistance index }\end{array}$ & $0,68 \pm 0,03$ & $0,78 \pm 0,05$ & 0,099 \\
\hline $\begin{array}{c}\text { Upper mesenteric } \\
\text { artery resistance index }\end{array}$ & $0,69 \pm 0,03$ & $0,71 \pm 0,06$ & 0,766 \\
\hline
\end{tabular}

cardioscopic and dopplerographic parameters in groups of children stratified according to the eNOS genotype, but no expected significant changes were detected (Table II).

Given the above results, it can be concluded that there is no effect of $4 \mathrm{a} / 4 \mathrm{~b}$ polymorphism of the eNOS gene on the occurrence of hemodynamic disturbances in premature infants with sepsis.
Diagnosis and treatment of hypertension in prematurely born children is one of the significant problems that clinicians face in their daily practice. There are many debatable issues, for example, how to determine the reference parameters of blood pressure in premature babies, which can cause severe pathological changes in this particular group of patients. It is generally accepted that arterial hypotension occurs in premature infants, when the average blood pressure level is lower than the gestational age of the child or below $30 \mathrm{~mm} \mathrm{Hg}$, because it is believed that these blood pressure numbers are critical for brain damage [7-8]. There are studies that indicate a lack of relationship between thelevel of cerebral blood flow and systemic blood pressure in prematurely born children [9] and suggest the presence of intact cerebral blood flow in such patients with critical numbers of systemic blood pressure [10]. To solve the question of the need for aggressive medical intervention, it is necessary to evaluate arterial hypotension in combination with other indicators of the clinical condition of the child [11] and taking into account possible genetic determinants.

\section{CONCLUSIONS}

Our study showed that in premature infants, the development of hypotension during sepsis is not associated with the presence of a polymorphic variant of the eNOS gene, however, we believe that it is necessary to continue the study in a larger sample of patients, as well as to study the effect of polymorphism of other genes, for example, the renin-angiotensin system, on the development of disorders of systemic hemodynamics.

\section{REFERENCES}

1. Stefanovic I.M. Neonatal sepsis. Biochemia Medica. 2011;21 (3):276281.

2. Plachta N., Traister A., Weil M. Nitric oxide is involved in establishing the balance between cell cycle progression and cell death in the developing neural tube. Exp Cell Res. 2003;288 (2):354-362.

3. Mattila J.T., Thomas C. Nitric oxide synthase: non-canonical expression patterns. Front Immunol. 2014; 5:478.

4. Miyahara K., Kawamoto T., Sase K. Cloning and structural characterization of the human endothelial nitric-oxide-synthase gene. Eur J Biochem. 1994; 223(3):719-726.

5. Demirçubuk A.G., Coşkun M.Y., Demiryürek S. et al. Endothelial NOS gene Glu298Asp polymorphism in preterm neonates with respiratory distress syndrome. Pediatr Pulmonol. 2013;48(10): 976-980.

6. Tsukada T., Yokoyama K., Arai T. et al. Evidence of association of the ecNOS gene polymorphism with plasma NO metabolite levels in humans. Biochem Biophys Res Commun. 1998;245:190-193.

7. Evans N. Assessment and support of the preterm circulation. Early Hum Dev. 2006; 82:803-10.

8. Kluckow M., Evans N. Low superior vena cava flow and intraventricular hemorrhage in preterm infants. Arch Dis Child Fetal Neonatal Ed. 2000;82:188-94.

9. Miall-Allen V.M., de Vries L.S., Whitelow A.G. Mean arterial blood pressure and neonatal cerebral lesions. Arch Dis Child. 1987;62:1068-9.

10. Tyszzzuk L., Meek J., Elwell C. et al. Cerebral blood flow is independent of mean arterial blood pressure in preterm infants undergoing intensive care.Pediatrics. 1998;102:337-41. 
11. Dempsey E.M., Hazzani F., Barrington K.J. Permissive hypotension in the extremely low birthweight infant with signs of good perfusion. Arch Dis Child Fetal Neonatal Ed. 2009; 94:241-4.

This article was written in the frames of Scientific research work "To develop and to implement a system of medical and psychological support for newborns at risk of chronic morbidity, disability and developmental delay". 0117U004538.

\section{ORCID and contributorship:}

Yuliia I. Cherniavska - 0000-0002-4522-7538 ${ }^{B, D}$

Valeriy I. Pokhylko - 0000-0002-1848-0490 A,F

Tetiana K. Znamenska - 0000-0001-5402-1622 ${ }^{\text {A,E }}$

Olga V. Vorobiova - 0000-0001-5199-0217 B,E

Nataliia I. Hasiuk - 0000-0001-5387-317X ${ }^{C, D}$

\section{Conflict of interest:}

The Authors declare no conflict of interest.

\section{CORRESPONDING AUTHOR}

Yuliia I. Cherniavska

Department of Pediatrics No1 with propedeutics and neonatology Ukrainian Medical Stomatological Academy

23 Schevtchenka str, 36000 Poltava, Ukraine

tel: +380661186555

e mail: ycherniavska32@gmail.com

Received: 01.03 .2020

Accepted: 07.05 .2020 